Yerokhin A.,

Zatserklianyi H.

\title{
DEVELOPMENT OF INFORMATION TECHNOLOGY FOR HEAT LOSSES MANAGEMENT OF CONSTRUCTION STRUCTURES
}

Об’єктом дослідження є непродуктивні тепловтрати у будинках і будівельних спорудах, обумовлених характером тепломасообмінного процесу, який функціонує у складній архітектурно-конструктивній схемі. Одним зі шляхів зменшення непродуктивних тепловтрат у будинках і будівельних спорудах є використання інформаційно-управляючих технологій та систем для управління такими об'єктами. Ці технологї та системи на основі опрацювання інформації про стан будівель і будівельних споруд повинні забезпечувати формування ефективних управлінських рішень, спрямованих на зменшення непродуктивних тепловтрат i оптимізацію структури споживання паливно-енергетичних ресурсів у житлово-комунальному секторі. На съогодні як в системах управління енергоефективністю будинків, так $і$ поза ними, тепломасообмінні процеси аналізуються або в найпростішій постановці, або в окремих елементах архітектурно-конструктивної схеми будівельної споруди. Такий підхід до моделювання тепломасообмінного процесу не забезпечує достатньо повне оцінювання непродуктивних тепловтрат. Це обумовлено тим, що сам процес тепломасообміну є складною взаємопов'язаною та взаємообумовленою системою та функціонує у складній архітектурно-конструктивній системі будівельної споруди. В даній роботі пропонується компонентноорієнтована інформаційна технологія, яка спирається на математичну модель взаємопов'язаного та взаємообумовленого тепломасообмінного прощесу, що функціонує в будь-якій складній архітектурно-конструктивній схемі будинку чи будівельної споруди. Ця модель порівняно з іншими використовуваними моделями охоплює всі основні властивості тепломасообміну як в огороджувальних конструкціях, так i в пароповітряних просторах. Вона враховує надходження тепла у приміщення будинку від систем опалення та освітлення, сонячної радіації та людей, які перебувають у будинку. А отже, дозволяє більш повно оцінити тепловтрати в будинку чи будівельній споруді.

Ключові слова: взаємопов'язаний та взаємообумовлений тепломасообмінний процес, моделювання тепломасообміну, інформачійно-управляючі технологіі.

Received date: 08.11.2019

Accepted date: 29.11.2019

Published date: 28.02 .2020
Copyright (C) 2020, Yerokhin A., Zatserklianyi H. This is an open access article under the CC BY license (http://creativecommons.org/licenses/by/4.0)

\section{Introduction}

Information technologies associated with the use of modern computer technology and data collection and transmission tools open up new possibilities in solving the problems of managing heat losses in the housing and communal sector. One of the ways to improve the energy efficiency of buildings and building structures is to use information management technologies and systems to manage the energy efficiency of such facilities. Based on information processing on the state of buildings and construction structures, these systems should ensure the formation of effective management decisions aimed at optimizing the structure of consumption of fuel and energy resources.

This work is aimed at solving an urgent scientific and applied problem, which is to reduce unproductive heat losses in buildings and construction structures, due to the nature of the heat and mass transfer process. This study can be considered as a logical continuation of the work [1].

\section{The object of research and its technological audit}

The object of research in this work is the heat loss of a building structure. This object is not well understood, because it is due to the complex heat-exchange processes, which operates in the architectural and structural design of the house. The study of this object should be based on mathematical modeling in the framework of modern information technologies.

\section{The aim and objectives of research}

The aim of research is developing information technology for working with data, models and methods in assessing the heat loss of building structures in an energy efficiency management system. To achieve this aim, it is necessary to complete the following objectives:

1. To build a structural-functional diagram of a decision support system for evaluating heat losses in a house or building. 
2. To develop requirements for the creation and formalization of the process of building information technology for analysis and evaluation of the interconnected and interdependent heat and mass transfer process in the energy efficiency management system of buildings and construction structures.

\section{Research of existing solutions of the problem}

In recent years, the scientific community has been working to substantiate, develop schemes and components of energy efficiency management systems. Energy management systems, in particular, include the system proposed in [2]. A detailed review of the energy efficiency management systems of building structures is given in [3].

In [4], the effect of atmospheric disturbances on the heat transfer of building components of the exterior walls of buildings is studied. The effect of convective heat transfer indoors is not taken into account. A numerical analysis of the influence of the thermal conductivity coefficient of various building materials on heat and mass transfer in a square cavity is given in [5]. The two-dimensional equations of conservation of mass, momentum, energy, and concentration with the turbulent $k$ - $\varepsilon$ model are solved by the finite volume method. The problem of determining the heat flux through the outer walls is not considered.

In [6], a numerical study of natural convection during unilateral and cross ventilation by the finite volume method is carried out taking into account the influence of internal heat sources. In [7], the main thermal processes in automated management systems for heat consumption by buildings are considered. It is also revealed that the effectiveness of these systems depends on external and internal factors.

There are a number of software packages for the comprehensive study of heat transfer processes in buildings. These include, but are not limited to:

- DOE-2 (DOE-2.3), developed by Lawrence Berkley

National Laboratory, USA [8];

- EnergyPlus (EnergyPlus 8.1.0), developed by Lawrence Berkley National Laboratory, USA CERL, University of Illinois, USA [9];

- BSim, developed by Danish Building Research Institute, Denmark [10];

- ESP-r, developed by Universitu of Strathclyde, UK [11].

These programs are based on national regulatory building documents and hidden mathematical models that are the basis of their calculation algorithms. And this complicates their correct application in construction practice. In addition, as shown by studies [12] conducted to assess the validity of these computer programs, the calculation results can vary significantly depending on the selected computer program.

So, the analysis shows that the consideration of heat transfer processes in energy efficiency management systems is performed either in individual elements of a building structure, or in a simple statement. However, this is not enough to find ways to achieve the possible energy efficiency of the building using the information control system. Thus, there is a need for such software that would consider heat and mass transfer as the only interconnected and interdependent process for any architectural design of a building or construction. Such software should be submitted within the framework of information technology.

\section{Methods of research}

The following scientific methods are used in research: - well-established approaches to building information systems for decision support;

- well-established approaches to building information technology for working with data, models and methods.

\section{Research results}

The component-oriented information technology model that is proposed in this paper is implemented in the decision support subsystems and the development of a management action to achieve a certain energy efficiency of the studied object. One of the main tasks of this technology is the formation of a set of mathematical models of data processing and analysis [13]. In this paper, models developed in [1] are chosen as mathematical models.

This implies the tasks of formalizing data and domain knowledge:

- creation of an interface for collecting and exchanging between databases and a database of models and methods;

- creation and improvement of mathematical models

of the studied processes of the subject area;

- task of developing the presentation of data and knowledge.

The structural and functional diagram of the developed decision support system for evaluating heat losses in the energy efficiency management system is shown in Fig. 1.

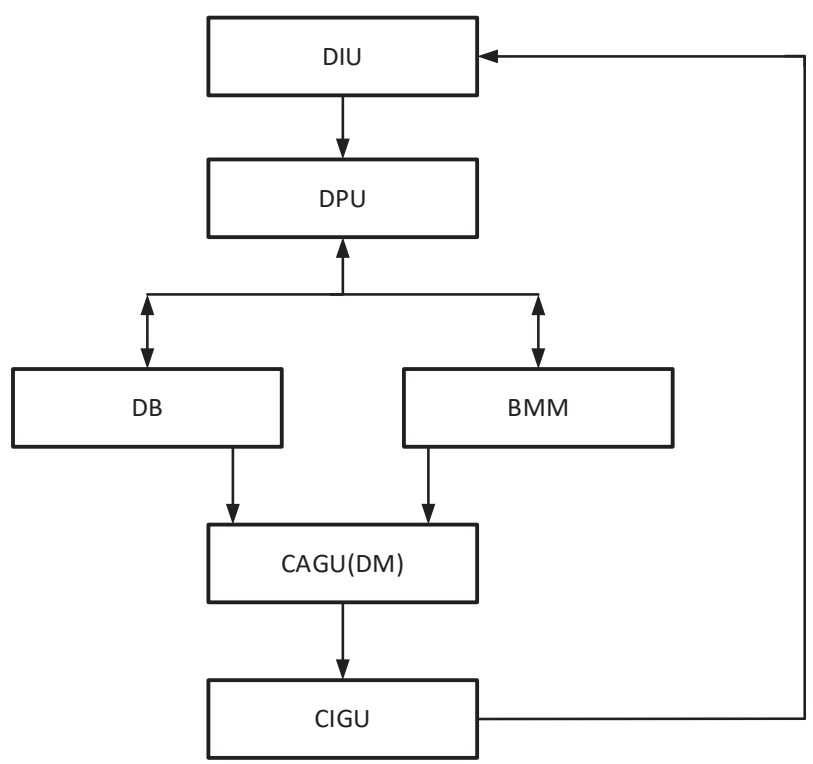

Fig. 1. Structural and functional diagram of a decision support system for evaluating the heat and mass transfer process in an energy efficiency management system

In Fig. 1 the following designations are given: DIU - data input unit; DPU - data preprocessing unit; DB - databases; BMM - block of models and methods; CAGU (DM) control action generation unit; CIGU - control information generation unit.

Control information includes:

- geometric parameters and material of the elements

of the building envelope;

- parameters of the vapor space; 
- type and geometrical and thermophysical parameters of heating and cooling systems;

- type of lighting system;

- the number of people in the room at which the heat and mass transfer process was simulated;

- integral characteristics of heat and mass transfer and the like.

On the basis of this information, the decision maker forms a managing influence, which consists in replacing the parameters within acceptable limits that characterize the material and geometric parameters of the building envelope elements; geometric and/or thermophysical parameters of the heating system and the like.

The parameters of the management object recommended by the decision maker are transferred to the data collection unit and the process of searching for ways to improve the heat consumption of the house or building construction continues iteratively.

Control information is accumulated in the data warehouse, which is relational OLAP (online analytical processing - real-time analytical processing).

So, in general terms, the model of processes for assessing heat and mass transfer in an energy efficiency management system is presented as a set of supporting functional processes and relationships that link these processes into a single $I S$ structure. It is formalized using the expression:

$$
I S=<P I, P M M, P D, P B, P D M>,
$$

where $P I$ - data exchange process; $P M M, P D$ - data storage processes in the database of models and methods and databases, respectively; $P B$ - data processing processes (development of control information); $P D M$ - process of generating management action.

Each process is a block having information inputs, outputs and resources used. The resources are supported by methods, models and data/knowledge, which, if necessary, are used to implement the process.

Let's formulate the requirements for the creation and formalization of the process of building information technology.

For the appropriate methodological support for evaluating the heat and mass transfer process in the energy efficiency management system, this paper proposes a method for constructing information technology, which consists of the following steps:

Stage 1. Formation of a model of information technology for assessing the heat and mass transfer process. The information technology model is a set of interconnected processes and objects that somehow participate in these processes. The objects in this case are:

- data structure $(S D)$;

- complex of mathematical models and methods (CMM);

- set of information processes (SIP);

- interaction of processes among themselves (ISIP).

Stage 2. Database formation. The data structure determines the information complex - the database of the parameters of the investigated object.

Stage 3. Formation of a complex of mathematical methods and models. The complex of mathematical models and methods contains an object model of an interconnected and interdependent process of heat and mass transfer, a model for assessing basic heat transfer processes, a model for matching processes in the elements of the architectural design of buildings and construction structures.

Stage 4. Formation of a complex of information processes. The complex of information processes consists of the processes of data preprocessing and data warehouse formation, obtaining from the data warehouse the necessary data and the necessary mathematical methods from the base of mathematical methods and models for solving a specific problem.

Thus, component-oriented information technology for evaluating the heat and mass transfer process allows to formalize the functional modeling of this process and obtain control information for the decision-maker to develop a management action on the object of study in order to achieve certain energy efficiency.

Interaction of processes among themselves (ISIP) is ensured by the functioning of the information system for decision support and is interpreted using a data flow diagram. Thus, the interaction of processes among themselves (ISIP) can be formalized using the expression:

$$
I S I P=<T S, D P, D A, R P>,
$$

where $T S$ - information processes for the preparation of initial data for evaluating the heat and mass transfer process in energy efficiency management systems; $D P$ - information processes for the selection of methods for assessing the parameters of the heat and mass transfer process in energy efficiency management systems; $D A$ - information processes of the choice of algorithm; $R P$ - information processes for the production of control information for the decision maker.

The process of assessing heat and mass transfer in energy management systems of buildings and construction structures requires a large amount of input data. Among them are the geometric and thermophysical parameters characterizing the building envelope, the external environment, steam and air spaces, heat input and absorption systems, and the like. These values are obtained in different ways: from automatic energy monitoring systems, direct measurement, from reference books, etc. They are usually provided in various units and in various formats.

In this case, two types of initial data are distinguished: variables that depend on the particular object under study and the parameters of its equipment. As well as relatively constant, characterizing the thermophysical parameters of the elements of the building envelope and the parameters of the methods for calculating some heat sources:

$$
S D=<S D_{s}, S D_{v}>
$$

where $S D_{s}$ - a set of stable source data; $S D_{v}$ - a set of variable source data.

Steel data are supplied by geometric and thermotechnical indicators of building materials and structures, the main technical data of heating and lighting systems, heat generation from people and the like.

This data is made out in the form of a relational database, reduced to the third normal form, and stored in the data warehouse. Information from these databases is obtained using SQL queries:

1. A centralized database of the energy efficiency management system, which is filled both by monitoring entities and automatically, and which stores information using a relational approach to database management. 
2. A repository that stores information through a nonrelational approach to data management.

3. Structured information that is stored as files or that is entered directly by the user.

Information technology analysis of this data is as follows.

At the first stage of the functioning of information technology, the source data is needed. They are obtained through an SQL query (Structured query language - a declarative programming language for user interaction with databases) to data storages (based on a relational or nonrelational DBMS (database management system). The data obtained at this stage is saved. Information technology supports the ability to independently enter data by the user. As a rule, this happens by downloading data from a file resource or manually. After receiving information from remote and sources and independent input of information proceed to the next stage.

The second stage of information technology is to eliminate duplication of the data obtained, bringing them to a single format and to a dimensionless form.

At the third stage, the generated data are checked for admissibility and sufficiency for the indicated methods of analysis and assessment of the heat and mass transfer process with the corresponding models of heat exchange interaction. In the case when the amount of data is not enough, there is a return to the stage of requesting data from additional data sources.

The fourth stage of the work is to simulate the heat and mass transfer process with the existing source data and the indicated modeling tools to generate control information that is transmitted to the decision maker.

The process of obtaining control information is implemented as a sequence of interrelated actions or functions. This implementation at each time step is reduced to the following steps:

1. Determination of heat gain due to convection and radiant radiation using the corresponding elementary blocks. Transferring results to a module for evaluating convective heat and mass transfer.

2. Assessment of convective heat and mass transfer in the corresponding elementary blocks. Transferring results to a module for assessing thermal conductivity through a solid wall.

3. Assessment of heat transfer due to thermal conductivity through a solid wall.

4. Assessment of heat loss through the building envelope.

5. Assessment of heat and mass transfer process, development of control information.

The implementation of the information process is performed on a certain period of time. The time step of the simulation is variable. Moreover, the implementation of each step includes 3 stages:

1. Each elementary block of the system receives information about the state of those blocks that affect it at a given time.

2. Each block of the system calculates its state at the next moment in time, taking into account the magnitude of the current simulation step (without passing to the next state). The calculations are performed based on the corresponding submodel of the elementary block of the system.

3. Each block implements (translates itself into) the following state.
At the fifth stage, based on the control information, the decision maker forms a managing influence. It consists in changing the parameters within acceptable limits characterizing the thermophysical and geometric parameters of the building itself or its engineering equipment. The parameters of the control object recommended by the decision maker are transferred to the data collection unit and the process of finding ways to improve the energy consumption of the house or building construction continues iteratively. In addition, control information is accumulated in the data warehouse, which is relational OLAP. The choice of this type of storage is due to the possibility of operating the information system as an independent system, or as a separate functional module of the energy efficiency management system of a house or building.

At the sixth stage of information technology, the control data accumulated in the storage is provided in appropriate form to appropriate specialists for making a final decision on the choice of a means of achieving possible energy efficiency.

Let's formalize the complex of mathematical models and methods using the expression:

$$
C M M=<C M M_{T C}, C M M_{C H T}, C M M_{R}, C M M_{T O}>\text {, }
$$

where $C M M_{T C}$ - methods for assessing thermal conductivity [8]; $C M M_{C H T}$ - methods for assessing convective heat transfer [9]; $C M M_{R}$ - methods for assessing radiation exposure [10]; $C M M_{T O}$ - methods for implementing models of heat exchange interactions [10].

Methods for assessing thermal conductivity include threedimensional $C M M_{T C} 3$ and one-dimensional $C M M_{T C} 1$ models implemented using the modified finite element method [8]:

$$
C M M_{T C}=<C M M_{T C} 3, C M M_{T C} 1>.
$$

Methods for assessing convective heat transfer include methods based on the unsteady, three-dimensional, turbulent flow of the $C M M_{C H T} 3$ vapor-air mixture implemented by the finite volume method, and on the quasistationary model $C M M_{C H T} 0$ implemented by the Runge-Kutta method [9]:

$$
C M M_{C H T}=<C M M_{C H T} 3, C M M_{C H T} 0>\text {. }
$$

The methods based on the Stefan - Boltzmann model [10] are among the methods for assessing radiation.

Methods for implementing models of heat exchange interactions cover models for determining the intensity of sources and sinks of mass, momentum, energy, including those that supply heat from lighting and heating systems, solar radiation, and people [11]:

$$
\begin{aligned}
& C M M_{T O}= \\
& =<C M M_{T O n}, C M M_{T O h}, C M M_{T O l s}, C M M_{T O s}, C M M_{T O p}>,
\end{aligned}
$$

where $C M M_{T O n}$ - income (loss) of the vapor-air mixture through the face or its part of a certain volume; $C M M_{T O h}-$ heat input from the heating system; $C M M_{T O l s}$ - heat input from the lighting system; $C M M_{T O S}$ - heat input due to solar radiation; $C M M_{T O p}$ - heat input from people.

When determining the heat input from the heating system, the following types of heating systems are provided:

- traditional heating system (window sill radiators of various types) $C M M_{T O h} 1$; 
- non-traditional heating systems with liquid coolant (underfloor heating, heating panels, etc.) $C M M_{T O h} 2$;

- using electric heating $C M M_{T O h} 3$ :

$$
C M M_{T O h}=<C M M_{T O h} 1, C M M_{T O h} 2, C M M_{T O h} 3>.
$$

Let's formalize the set of information processes $(S I P)$ using the expression:

$$
S I P=<D C, P P, E I, S I, P R>,
$$

where $D C$ - data collection process; $P P$ - data preprocessing process; $E I$ - process of obtaining control information; $P R-$ decision making process and the saving obtained results.

The process of preliminary processing of PP data is based on the following operations:

- A1 - elimination of data duplication;

- $A 2$ - reduction to a single presentation format;

- A3 - obtaining dimensionless quantities.

Interaction of processes among themselves (ISIP) is ensured by the functioning of the information system for decision support and is interpreted using a data flow diagram. Thus, the interaction of processes among themselves (ISIP) can be formalized using the expression:

$$
I S I P=<T S, D P, D A, R P>,
$$

where $T S$ - information processes for the preparation of initial data for evaluating the heat and mass transfer process in energy efficiency management systems; $D P$ - information processes for the selection of methods for assessing the parameters of the heat and mass transfer process in energy efficiency management systems; $D A$ - information processes of the choice of algorithm; $R P$ - information processes for the production of control information for the decision maker.

\section{SWOT analysis of research results}

Strengths. The proposed information technology provides a computational experiment to find means of reducing unproductive heat loss of a building.

Weaknesses. The weaknesses of this research include the fact that when implementing the algorithm in the framework of the proposed information technology, it is large, and this is important when solving the optimization problem. This disadvantage is compensated by the use at certain stages of the implementation of the optimization task of simpler models of the heat and mass transfer process.

Opportunities. It is planned to apply the results for the analysis of heat transfer processes in other objects.

The results obtained in this work allow, when assessing the heat transfer processes of houses and building structures, to «lose» the behavior of these objects under various conditions and with various modifications, to vary the structural and functional parameters of these objects. Therefore, more fully take into account the characteristics of heat and mass transfer in energy efficiency management systems.

Threats. There are foreign analogues of information technologies, but their mathematical support is unknown.

\section{Conclusions}

1. A structural and functional diagram of the decision support system for assessing heat loss as a component of the energy efficiency management system of a house or building structure has been built. This system provides control information on the basis of which the decision maker iteratively controls the search for a means of achieving one or another possible energy efficiency of a house or building.

2. A model of information technology has been developed, which is a set of interrelated processes and objects that participate in these processes in one way or another. The objects in this case are:

- data structure $(S D)$;

- complex of mathematical models and methods (CMM);

- set of information processes (SIP);

- interaction of processes among themselves (ISIP).

\section{References}

1. Yerokhin, A. L., Zatserklyanyy, G. A. (2016). Development of the object-oriented model for the health losses analysis in the non-process building. Technology Audit and Production Reserves, 5 (1 (31)), 26-34. doi: http://doi.org/10.15587/ $2312-8372.2016 .80561$

2. Oung, K. (2013). Energy Management in Business: The Manager's Guide to Maximising and Sustaining Energy Reduction. Gower Publishing, 278. doi: http://doi.org/10.4324/9781315579559

3. De Paola, A., Ortolani, M., Lo Re, G., Anastasi, G., Das, S. K. (2014). Intelligent Management Systems for Energy Efficiency in Buildings. ACM Computing Surveys, 47 (1), 1-38. doi: http:// doi.org/10.1145/2611779

4. Janssen, H., Blocken, B., Carmeliet, J. (2007). Conservative modelling of the moisture and heat transfer in building components under atmospheric excitation. International Journal of Heat and Mass Transfer, 50 (5-6), 1128-1140. doi: http://doi.org/ 10.1016/j.ijheatmasstransfer.2006.06.048

5. Gijón-Rivera, M., Serrano-Arellano, J., Xamán, J., Álvarez, G. (2016). Effect of different building materials on conjugate heat and mass transfer. Ingenier. mecáni. tecnolog. Desarroll, 5 (4). Available at: http://www.scielo.org.mx/scielo.php?script=sci arttext\&pid=S1665-73812016000100395

6. Rocha, L. J. C., Souza, H. A. (2016). Numerical study of the influence of internal heat source in naturally ventilated offices. Rem: Revista Escola de Minas, 69 (1), 45-51. doi: http://doi.org/ 10.1590/0370-44672015690099

7. Tsynaeva, E., Tsynaeva, A. (2017). The study of thermal processes in control systems of heat consumption of buildings. Problems of Thermal Physics and Power Engineering. Moscow. doi: http://doi.org/10.1088/1742-6596/891/1/012159

8. The home of DOE-2 based building energy use and cost analysis software. Available at: http://www.doe2.com/

9. Energy plus energy simulation software. U.S. Department of Energy. Available at: http://elearning-southzeb.eu/mod/page/ view.php?id=111

10. Statens byggeforskningsinstitut. Available at: http://www.sbi. $\mathrm{dk} /$ indeklima/simulering

11. ESP-r. Available at: http://www.esru.strath.ac.uk/Programs/ ESP-r.htm

12. Zhu, D., Hong, T., Yan, D., Wang, C. (2013). A detailed loads comparison of three building energy modeling programs: EnergyPlus, DeST and DOE-2.1E. Building Simulation, 6 (3), 323-335. doi: http://doi.org/10.1007/s12273-013-0126-7

13. Rohdin, P., Moshfegh, B. (2011). Numerical modelling of industrial indoor environments: A comparison between different turbulence models and supply systems supported by field measurements. Building and Environment, 46 (11), 2365-2374. doi: http://doi.org/10.1016/j.buildenv.2011.05.019

Yerokhin Andriy, Doctor of Technical Sciences, Professor, Department of Software Engineering, Kharkiv National University of Radio Electronics, Ukraine, ORCID: http://orcid.org/0000-0002-8867-993X, e-mail: andriy.yerokhin@nure.ua

Zatserklianyi Heorhii, Department of Software Engineering, Kharkiv National University of Radio Electronics, Ukraine, ORCID: http:// orcid.org/0000-0002-9258-9013,e-mail:george.zatserklyany@gmail.com 